\title{
Perspectives of the App Economy: Tenets of the Innovative Phenomenon
}

\author{
Ciro Troise ${ }^{1}$, Elia Ferrara ${ }^{2}$, Mario Tani ${ }^{4} \&$ Ornella Papaluca ${ }^{3,4}$ \\ ${ }^{1}$ Department of Management, Università degli Studi della Campania “Luigi Vanvitelli”, Capua (CE), Italy \\ ${ }^{2}$ Italian Competition Authority "Antitrust”, Rome (RM), Italy \\ ${ }^{3}$ Stazione Zoologica Anton Dohrn - National Institute of Marine Biology, Ecology and Biotechnology, Villa \\ Comunale 1 - 80121 - Naples, Italy \\ ${ }^{4}$ Department of Economics, Management, Institutions, University of Naples Federico II, Naples, Italy \\ Corrispondence: Ornella Papaluca, Stazione Zoologica Anton Dohrn - National Institute of Marine Biology, \\ Ecology and Biotechnology, Villa Comunale 1 - 80121 - Naples, Italy.
}

Received: January 14, 2020

Accepted: January 30, 2020

Online Published: January 30, 2020

doi:10.5539/ibr.v13n3p1

URL: https://doi.org/10.5539/ibr.v13n3p1

\begin{abstract}
The paper aims to explore the App Economy drawing on a configurational multiple-theory perspective (Meyer, Tsui \& Hinings 1993; Miller, 1996), using the lens of Transaction Costs Theory, Regulation, Disruptive Innovation Theory and Systemic Approach. These theories are examined in the form of tenets. The choice of these theories as dimensions of our model is the output of two different activities. The first regards an ex-ante analysis of the previous studies in this field in order to find less investigated perspectives and find a connection between the topic of the App Economy and the main management theories; the second refers to a debate with some strategic management scholars in order to identify and choice the main theories for this research.

This paper contributes to the existing literature by proposing an original interpretation of the App Economy and it tries to add new knowledge in this emerging research field by adding new tenets. The results of study are the formulation of eight different tenets: two for Transaction Costs Theory, one for Regulation, three for Disruptive Innovation Theory and two for Systemic Approach. These results have confirmed the linked between chosen theories and the new research field of the App Economy. In any case, this paper is a preliminary study to develop a theoretically grounded approach to understanding the emergence of the App Economy and how manage the changes that it brings into the markets. This study has implications for several stakeholders (such as managers, enterprises, institutions, Authorities, app developers, operators, platform managers and other organizations that work in this field), and for several industries being impacted by developments induced by this innovative sharing economy.
\end{abstract}

Keywords: App economy, App ecosystem, authorities, disruptive innovation, mobile Apps, regulation, sharing economy, systemic approach, stakeholder, transaction cost

\section{Introduction}

\subsection{Introduce the Problem}

In the last few years, the phenomenon of the so-called App Economy has had a disruptive impact on the world economy and significant implications for a multitude of stakeholders.

Mulligan and Card (2014: 3) reported that "the global App Economy can trace its origins to the launch of Apple's iTunes App Store in 2008, but it is still a market in its infancy". About a decade ago, the term app became commonly understood, even if the first software application was created many years before ${ }^{1}$ (Goldsmith, 2014). App is shorthand for application, and it is a "standardized piece of software that runs on a computing platform" (OECD, 2013: 8). These applications include software for mobile devices, tablets and a wide range of other devices such as desktop computer.

Today, Apps are a necessity in both technical and commercial fields (Serrano, Hernantes \& Gallardo, 2013), and their advent presents many opportunities for entrepreneurs and companies. In fact, since the origin of Apps, MacMillan and Burrows (2009) highlighted that some startups that staked their claim in the App Economy have 
become large, lucrative businesses in just a few months. A decade after entering the global scene, the App Economy is still very topical. The main reasons are related to its evolutions and the multitude of fields of interest or use.

The recent global reports show very significant numbers and table 1 summarizes the main elements.

Table 1. App Economy: main numbers

\begin{tabular}{|c|c|c|}
\hline Parameter & Numbers and Growth rates & Source \\
\hline Apps available & $\begin{array}{c}\text { Number of Apps available (March 2017): } 2.8 \text { million on Google } \\
\text { Play and } 2.2 \text { million on Apple App Store }\end{array}$ & EPRS (2018) \\
\hline U.S. App Economy & $\begin{array}{l}\text { In the United States alone, the App Economy has grown from U.S. } \\
\$ 1.9 \text { billion in } 2008 \text { to U.S. } \$ 143 \text { billion in } 2016\end{array}$ & EPRS (2018) \\
\hline Freemium Apps & $\begin{array}{c}\text { In 2018, free Apps constitute } 95 \% \text { of total Apps commercialized in } \\
\text { the Google Play Store }\end{array}$ & $\begin{array}{l}\text { Cecere, Le Guel \& } \\
\quad \text { Lefrere (2018) }\end{array}$ \\
\hline $\begin{array}{l}\text { Global App users - } \\
\text { spending }\end{array}$ & $\begin{array}{l}\text { In } 2021 \text { the number of global App users will reach } 6.3 \text { billion people } \\
\text { and increase spending from } \$ 379 \text { to } \$ 1008 \text { per person }\end{array}$ & EPRS (2018) \\
\hline $\begin{array}{l}\text { EU App Employment } \\
\text { and intensity* }\end{array}$ & $\begin{array}{c}\text { In 2017, European App Economy includes } 1.89 \text { million jobs and has } \\
\text { an average intensity of } 0.84 \% \text {. }\end{array}$ & PPI (2017) \\
\hline $\begin{array}{l}\text { U.S. App Employment } \\
\text { and intensity* }\end{array}$ & $\begin{array}{c}\text { In 2017, U.S. App Economy includes } 1.73 \text { million jobs and has an } \\
\text { average App intensity of } 1.1 \% \text {. }\end{array}$ & PPI (2017) \\
\hline $\begin{array}{l}\text { EU App-developer } \\
\text { workforce (Forecast) }\end{array}$ & $\begin{array}{l}\text { The EU App-developer workforce will grow (forecast) from } 1 \\
\text { million in } 2013 \text { to } 2.8 \text { million in } 2018\end{array}$ & $\begin{array}{l}\text { Mulligan \& Card } \\
\text { (2014) }\end{array}$ \\
\hline $\begin{array}{l}\text { EU additional support } \\
\text { and marketing staff } \\
\text { (Forecast) }\end{array}$ & $\begin{array}{l}\text { Additional support and marketing staff result (forecast) in total App } \\
\text { Economy jobs of } 1.8 \text { million in } 2013 \text {, growing to } 4.8 \text { million in } \\
2018 \text {. }\end{array}$ & $\begin{array}{l}\text { Mulligan \& Card } \\
\text { (2014) }\end{array}$ \\
\hline $\begin{array}{l}\text { Mobile Device Install } \\
\text { Base }\end{array}$ & $\begin{array}{c}\text { The install base of smartphones and tablets to expand from } 3.9 \mathrm{~B} \text { at } \\
\text { the end of } 2017 \text { to } 6.1 \mathrm{~B} \text { in } 2022\end{array}$ & App Annie (2018) \\
\hline $\begin{array}{l}\text { Annual Mobile App } \\
\text { Downloads }\end{array}$ & $\begin{array}{l}\text { Global downloads will grow } 45.0 \% \text { from } 178.1 \mathrm{~B} \text { in } 2017 \text { to reach } \\
\qquad 258.2 \text { in } 2022\end{array}$ & App Annie (2018) \\
\hline $\begin{array}{l}\text { Annual Consumer } \\
\text { Spend in App Stores }\end{array}$ & $\begin{array}{l}\text { Global consumer will spend in App stores reaching } \$ 156.5 \mathrm{~B} \text { in } \\
2022 \text {. This is up } 92 \% \text { from } \$ 81.7 \mathrm{~B} \text { in } 2017 \text {. }\end{array}$ & App Annie (2018) \\
\hline $\begin{array}{l}\text { Average Annual } \\
\text { Consumer Spend }\end{array}$ & $\begin{array}{l}\text { Global average spend per device is projected to rise from \$20.94 in } \\
\qquad 2017 \text { to } \$ 25.65 \text { in } 2022\end{array}$ & App Annie (2018) \\
\hline $\begin{array}{l}\text { Global Spend (APAC - } \\
\text { China) }\end{array}$ & $\begin{array}{l}\text { APAC region is driving nearly two-thirds of the global spend as } \\
\text { China remains the world's largest market, hitting } \$ 62.4 \mathrm{~B} \text {, or nearly } \\
40 \% \text { of worldwide spend. }\end{array}$ & App Annie (2018) \\
\hline $\begin{array}{l}\text { Average Annual spend } \\
\text { per device in Japan }\end{array}$ & $\begin{array}{l}\text { Annual average spend per device in Japan will exceed } \$ 140 \text { by } 2022 \\
\text { - this is nearly } 6 \mathrm{x} \text { the global average and by far the highest in the } \\
\text { world. }\end{array}$ & App Annie (2018) \\
\hline $\begin{array}{l}\text { People own } \\
\text { smatrphones }\end{array}$ & $\begin{array}{l}\text { In 2018, the share of Americans that own smartphones are now } 81 \% \\
\text { (up from just 35\% in 2011). }\end{array}$ & PEW (2019) \\
\hline Time on mobile devices & Adults spend more than 5 hours per day on mobile devices & $\begin{array}{l}\text { Khalaf \& Kesiraju } \\
\text { (2017) }\end{array}$ \\
\hline Time in Apps & $87 \%$ of mobile time spent is in applications & App Annie (2016) \\
\hline Revenues & $\begin{array}{l}\text { Mobile applications are projected to have } \$ 100 \text { billion in revenues } \\
\text { in } 2020\end{array}$ & App Annie (2016) \\
\hline
\end{tabular}

Note. *App Economy jobs as a share of all jobs

Table 1 shows how the business is continuously and rapidly growing. To do an example, in the 2016 App Annie forecasted Worldwide, Apps are projected to have over $\$ 100$ billion in revenues in 2020 and over 258 billion downloads in 2022 (App Annie, 2018). In a report of Apple's App Store, the Company has reached a new record for revenue earned within 24 hours, accumulating \$386 million on New Year's Day 2020! The impact of mobile Apps on the global economy is tremendous. In the United States, for example, the App Economy has grown from U.S. $\$ 1.9$ billion in 2008 to U.S. \$143 billion in 2016. This tremendous impact is also evident in several other fields. Among them, the most important are the growth in employment, spending and timing. As for employment, App Economy includes 1.89 million jobs in Europe and 1.73 million in U.S. (PPI, 2017), while additional support and marketing staff result in about 4.8 million in 2018 (Mulligan \& Card, 2014). Global consumer will spend in App stores over \$156.5B in 2022 (in particular, APAC regions highlight significant 
growth rates) (App Annie, 2018) and a high number of people own smartphones (over 81\% of Americans) (PEW, 2019). A growing number of adults spend more than 5 hours per day on mobile devices (Khalaf \& Kesiraju, 2017) and $87 \%$ of mobile time spent is in applications (App Annie, 2016).

Also the literature in this research stream is still in its infancy as well as the market (Mulligan \& Card, 2014). Both scholars and practitioners are attracted by the development of the App Economy. The marketing perspective is predominant in the current literature, in fact many scholars examined business models and consumer perspectives (Wang, Liao, \& Yang, 2013; Taylor \& Levin, 2014; Hew, Lee, Ooi \& Wei, 2015; Arora, Ter Hofstede \& Mahajan, 2017; Chen, Zhang \& Zhao, 2017; Dinsmore, Dugan, \& Wright, 2016; Dinsmore, Swani, \& Dugan, 2017).

Over the years, scant attention has been paid to other perspectives and themes. In the present study, we focus our attention on some less investigated areas, and we explore the App Economy drawing on a configurational perspective (Doty, Glick \& Huber, 1993; Demers, 2007; Meyer, Tsui \& Hinings, 1993; Miller, 1996). Specifically, we adopt a multiple-theory configurational perspective and the four relevant theories considered are: Transaction Costs Theory (Coase, 1937; Williamson, 1979), Regulation (Chisholm \& Jung, 2015; Troise \& Ferrara, 2016), Disruptive Innovation Theory (Bower \& Christensen, 1995; Christensen \& Bower, 1996; Christensen, 1997; Christensen \& Overdorf, 2000; Christensen \& Raynor, 2003; Kostoff, Boylan \& Simons, 2004; Danneels, 2004; Markides, 2006) and Systemic Approach (Dominici, \& Levanti, 2011; Tani, Papaluca \& Sasso, 2019). These four dimensions are examined in the form of four tenets.

This paper contributes to the existing literature by proposing an original interpretation of the App Economy and it tries to add new knowledge in this emerging research field by adding new tenets. Explaining and contextualizing App Economy is complex, in fact there is an ongoing call for more research that contributes to improve the understanding of the developments of the phenomenon.

The paper is organized as follows. The next sections present the literature review, followed by a presentation of the research design. We next examine and discuss the four theories and the related tenets. The final section concludes the paper.

\subsection{Literature Review}

The rapid growth of the App Economy and its implications involve numerous scholars and practitioners (Hoehle \& Venkatesh, 2011). Recently, several of them have begun to explore how many types of industries benefit from this growth. In fact, the development of App Economy affects both traditional sectors and new emerging sectors. Well known examples of new sectors are taxi-hailing industry (i.e. Uber), hospitality industry (i.e. Airbnb) and sharing-economy industry such as carsharing or ridesharing (i.e. Drivy and BlaBlaCar) (Denning, 2014; Guttentag, 2015; Cramer \& Krueger, 2016; Ert, Fleischer \& Magen, 2016; Puschmann \& Alt, 2016; Dudley, Banister \& Schwanen, 2017; Johnston, 2017; Oei \& Ring, 2017; Remane, Hanelt, Nickerson, \& Kolbe, 2017; Zervas, Proserpio \& Byers, 2017; Basili \& Rossi, 2019; Farajallah, Hammond \& Pénard, 2019). In this vein, the current literature is rich in studies that investigate mobile Apps and their role in multisided or two-sided platforms. Many of these companies - that based their business on Apps - developed specific applications in order to connect two (or more) sides and to facilitate the transactions. The advent of applications has offered not only opportunities to new sectors but also to existing ones. In the last few years, in fact, many scholars focused on some specific types of Apps in several traditional fields, (i.e. healthcare, pharmacy and surgery). Some of these Apps are spreading worldwide, such as mobile medical Apps (Aungst, 2013), Apps for health care professionals (Ventola, 2014), Apps for physical activity (Conroy, Yang \& Maher, 2014) and so on. Other scholars focused on the geography of the App Economy (Mandel \& Scherer, 2012; Kathuria \& Srivastav, 2014). Mandel and Scherer (2012:3) argued that a peculiarity is that "the App Economy is simultaneously global, local, and intensely personal".

App Economy is a novel topic and the studies in this research stream are few and at the first stages. The first studies explored Apps in digital platforms (as above cited) or adopted a marketing perspective in order to investigate consumer's attitudes. A number of studies argued that consumer's choices and behaviors are different in mobile applications versus other consumption contexts. Several papers - in fact - suggested that some factors influence consumer behavior "in-App", including device type, application category, screen size, personality traits (Dinsmore et al., 2016; Dinsmore et al., 2017), design elements, pricing scheme (Arora et al., 2017; Dinsmore et al., 2016) and more. In this research field, other scholars explored the perspective of developers (Holzer \& Ondrus, 2011) or mobile application platforms (Grønli, Hansen, Ghinea \& Younas, 2014; Ma, Gu \& Wang, 2014).

The literature on App Economy has been poorly developed over the last decade and the issue still shows 
fragmented contributions. Over the years, scholars have mainly investigated this topic by focusing on platforms or consumer behavior, but little is known about other important areas. We propose a contribution based on a multi-perspective whose main purpose is to get an overview of the state-of-art on four strategic dimensions: Transaction Costs Theory, Regulation, Disruptive Innovation Theory and Systemic Approach. This wider perspective is useful to improve the understanding of the new phenomenon and shed some lights on less investigated fields. Thus, our study adds to the growing body of research on App Economy.

\section{Method}

We explore the App Economy by applying a multiple-theory configurational perspective. Many studies in several fields adopted a configurational perspective (Meyer et al., 1993; Homburg, Workman \& Jensen, 2002; Heirman \& Clarysse, 2004; Miller \& Le Breton-Miller, 2006; Raymond \& Croteau, 2006; Zimmermann, 2011; Henningsson \& Kettinger, 2016; Hofman, Faems, \& Schleimer, 2017; Straatmann, Rothenhofer, Meier \& Mueller, 2018; Windsor, 2019).

This specific type of perspective has been developed in Organizational Theory and has been gaining increasing attention over the years (Meyer et al. 1993; Miller 1990, 1996). Among the main fields of application, Strategic Management is one of the most recurrent (Herrmann, 2005; Hoskisson, Hitt, Wan, You, 1999; Mahoney \& McGahan, 2007; Mellahi \& Sminia, 2009).

The Configurational Approach is useful in complex social settings and in analyzing a new phenomenon (Henningsson \& Kettinger, 2016; Greckhamer, 2016; Windsor, 2019). This method has some advantages, among them, it facilitates the capture of some types of causal complexity or different conditions. Furthermore, many studies use tenets (Miller \& Le Breton-Miller, 2006; Freitas, Gonçalves, Cheng, \& Muniz, 2011; Drover, Wood \& Tyge Payne, 2013; Busenbark, Krause, Boivie \& Graffin, 2016) and highlighted their importance to develop future frameworks and develop different combinations or functions.

\subsection{Research Design}

Since this method is recurrent in the analysis of new phenomenon, we apply it to the App Economy, and we identify eight main tenets. In doing this, we focus on four main areas of the App Economy (fig. 1): Transaction Costs Theory, Regulation, Disruptive Innovation Theory and Systemic Approach. The choice of these precise points is the output of two different activities. The first regards an ex-ante analysis of the previous studies in this field in order to find less investigated perspectives and find a connection between the topic of App Economy and the main management theories; the second refers to a debate with some strategic management scholars in order to identify and choice the main theories for this research.

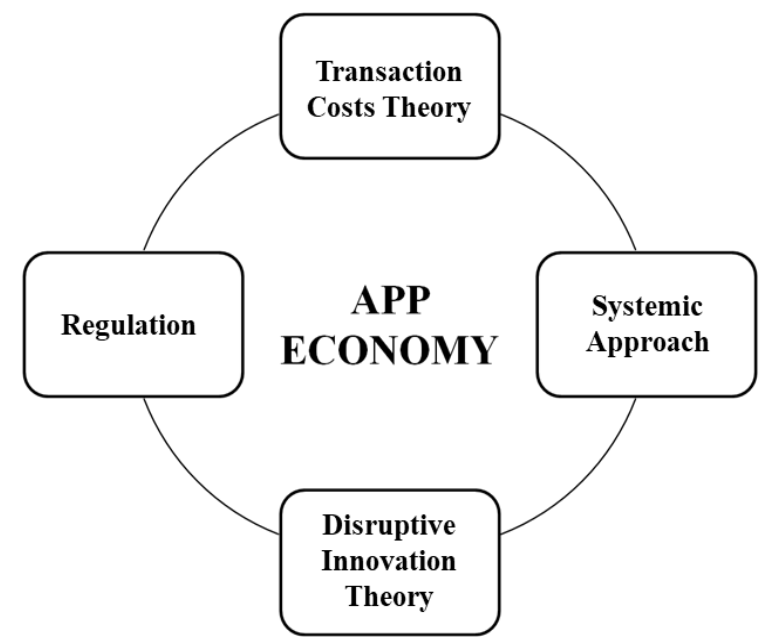

Figure 1. Framework: Perspectives of the App Economy

These tenets are meant to relate to the impact of Apps on the Global Economy, and more generally, on society of the future. The advent of mobile Apps offers a multitude of implications and effects for transaction costs, regulations, innovation and system economies. All tenets come with an implicit assumption that the Apps have had a significant influence on the players of the Ecosystem.

\subsubsection{Transaction Cost Theory}

Coase's Theorem (1937) has three main characteristics: reducing transaction costs; increasing social utility; and changing the nature of participating firms. 
In the last few years, a growing number of companies base their business on Apps. The ongoing activities and evolution of mobile App Companies are forcing a complete change and transformation in many markets and they may have a deep impact by reducing transaction costs. In particular, Apps may lessen some of the issues behind transaction costs, such as limited rationality, information asymmetry (Simon, 1957, 1985) and asset specificity (Williamson, 1979).

Henten and Windekilde (2015) suggested, referring digital platforms, that the transaction costs of searching, contacting, contracting, etc. would generally be much too high for some commercial markets without the Apps. So, we can adopt the transaction cost perspective to study prominent examples of the sharing economy such as carsharing (i.e. Drivy or Turo) and ridesharing (i.e. BlaBlaCar or Lyftshare) (Basili \& Rossi, 2019; Denning, 2014; Farajallah et al., 2019; Puschmann \& Alt, 2016), hospitality platforms (i.e. Airbnb, Booking, Trivago and Tripadvisor) (Ert et al., 2016; Guttentag, 2015; Zervas et al., 2017), store App (eBay or Amazon) and taxi-hailing platforms (i.e. MyTaxi, GetTaxi or Uber) (Cramer \& Krueger, 2016; Dudley et al., 2017; Johnston, 2017; Oei \& Ring, 2017; Remane et al., 2017).

In fact, Apps allow for decreasing transaction costs: for example, as they reduce the distance between sellers and buyers, and they help to provide several "extended services", they may be useful to business, such as Amazon or eBay; in the hospitality sector, Apps let consumers compare the price and services that each single room has on several on line stores, such as Airbnb or Booking (and, even more, Trivago and Tripadvisor), increasing the consumers' capability to make a conscious decision.

On the other hand, it's obvious that the sharing economy is transforming numerous industries. Akbara and Tracogna (2018) suggest that, in revising their business models to cope with the new competitive challenges posed by sharing economy, the Companies can leverage their superior capacity to deal with frequency, uncertainty and asset specificity (three main problems of Transactions Cost Theory) through App Economy.

So, considering these assumptions, decreasing transaction costs can advantage companies and/or consumers. Our tenets in this field can be defined as follow:

T1a. App Companies and their business actions are able to reduce transaction costs.

T1b. Apps may reduce transaction costs for many businesses in several fields, leveraging on the reduction of limited rationality and of the information asymmetry.

\subsubsection{Regulation}

Till now, the Authorities have attended in the sharing economy analyzing Digital Platforms and Apps as competitors of traditional enterprises (Ashton, 2009; Oriwoh \& Conrad, 2015). From this point of view, the presence of network externalities encourages the so-called tipping (Dubé, Hitsch, Chintagunt, 2010), defined as a phenomenon that allows the increase in a firm's market share dominance caused by indirect network effects.

Therefore, there are three possible sceneries (Rochet \& Tirole, 2010). In the first, there is a dominant App that works as a dominant Company and raises artificial barriers to market entry (Bresnahan, Davis \& Yin, 2015), offering, for example, bonuses or other forms of incentives to attract the maximum number of customers. In this way, on the demand side, customers will tend to become captive; instead of, on the supply side, this strategy allows developers to catch the best bidders, of which consumers have a greater trust. In the other scenario, the Digital Platform or an App can cut out a potential - or current - competitor, through its acquisition by incorporation. Last but not least, a dominant position can depend also from the barriers to market entry deriving from specific commercial contracts, such as the favorite nation clause and the exclusivity clause (OECD, 2013).

In any case, the growth of an App or Digital Platform - in terms of revenues or customers - does not necessarily have elements of competitive problems like a traditional Company with a dominant position. Furthermore, its strength cannot be immediately explained by the abusive exercise of monopoly power: for example, it is also possible that it has a better offer in qualitative and economic terms than its competitors (Troise \& Ferrara, 2016). Digital Platforms and Apps have distinctive features that are difficult to regulate without following a case by case approach.

As there the differences between several Apps and Digital Platforms, a so-called "Digital One Size Fits All" approach (Chisholm \& Jung, 2015) should be avoided in defining a regulatory framework. Instead of, it would be better to adopt different schemes that appropriately enhance the special characteristics of each platform. For example, Apple's strategy to close its operating system, can be effective in guaranteeing levels of safety and quality of service to consumers (West \& Mace, 2010). In the same way, Google's inverse strategy to open for the Android system, makes easy the entry on the market of operators who can interact with Android and, therefore, favors the testing of new applications. A priori, a regulator cannot establish which of the two strategies is more 
efficient; much better, if Apps and Digital Platforms competing freely decide their strategy of opening. This is a desirable solution unless there is an only one active platform, with no real alternatives either for consumers or for app developers. Therefore, the use of forms of regulation on behavioral obligations and / or on prices in the sharing economy is a hazardous. It is possible that the regulator acts too early, curbing the emergence of more innovative Apps and competitive Platforms and imposing excessive costs on incumbent (separate company, regulatory accounting, access prices). From this point of view, therefore, it would seem more appropriate to intervene through a renewed enforcement antitrust, which could analyze the competitive conditions generating from the entry on a market of a new App or Platform on a case by case. For example, it could be more efficient to prohibit concentrations between Apps and competing Digital Platforms (enforcement antitrust) rather than seeking the optimal degree of openness of an App and a Digital Platform (regulatory intervention), because the dynamism of the sector could lead to the emergence of Apps and Digital Platforms higher technologically.

For these reasons, we can formulate the tenets on the app economy referred on regulation as follow:

T2a. The Digital One Size Fits All cannot be applied to the App Economy.

\subsubsection{Disruptive Innovation Theory}

In the last few years, both scholars and practitioners have looked into the App Economy as a phenomenon of disruptive innovation. In fact, Apps have had a disruptive impact on the market and on traditional activities (Williams, 2012; Palekar, Weerasinghe \& Sedera., 2013; Cortez, 2014; Green, 2015). Their development has created enormous advantages for several businesses and for consumers by lowering the production of costs for companies and those of acquisition of products/services for final users. In particular, several Companies and entrepreneurs faced many opportunities for growth their business or start their new initiatives.

The innovation represented by Apps changes the rules of competition in many industries, revolutionizing entire markets, bringing to the top of many sectors both newcomers and start-ups, breaking the position of incumbents (Bower \& Christensen, 1995; Christensen \& Bower, 1996; Christensen, 1997; Christensen \& Overdorf, 2000; Christensen \& Raynor, 2003; Kostoff, Boylan \& Simons, 2004; Danneels, 2004; Markides, 2006).

This innovation has created new markets and a new population of consumers, allowing access to services and products through App stores.

The growth of App Economy attracted a large body of potential App demanders and it has created an explosion of App suppliers in several forms (Bresnahan et al. 2015). In recent years, many App developers have brought significant innovations to consumers, coming to offer alternative products or services more often through applications. For example, communication and message exchange services, such as WhatsApp or Messanger, have increasingly taken the place of traditional services offered by landline or mobile phones (i.e. phone calls, SMS or MMS). These services have posed a significant competitive threat to telecommunications operators, in fact, the telcos have shown a reduction in revenues attributed to services (both VoiP and messages) developed by OTT (over the top).

The rapid diffusion of Apps affected all the traditional businesses and the vast majority of fields. Rakestraw, Eunni and Kasuganti (2013) highlighted the strong impact of Apps on mobile gaming and on traditional websites. Other scholars suggested that health care sector knew many important effects of this innovation, in fact many studies showed that Apps improve quality of cares and safety of patients by providing easy (with cost reducing) and useful tools (Williams, 2012; Green, 2015).

Also, from the perspective of people, Apps have had a disruptive impact since they have wide uses for its vast functioning area and facilitate several people's activities (Islam, Islam \& Mazumder, 2010).

In this evolving scenario, companies try to exploit digital technologies to improve their businesses and products, while people try to increase their benefits.

The nature of Apps as a disruptive innovation has not yet been fully discussed in existing literature, but this topic is among the most developable in theory. Indeed, in the last years, different empirical evidences have emerged that allow to analyze specific cases, following the perspective of disruptive innovation. Furthermore, we have to consider the importance of other new technologies that are entering the global arena, such as big data (Chen et al., 2017). This offers many opportunities to study App Economy also by combining its effects with other new technologies.

On the basis on these assumptions, we argue that Apps are a disruptive innovation and they play a key role in influencing the traditional businesses and creating opportunities for new ones, thus changing drastically the current market. 
For these reasons, we can formulate the tenets on the App Economy referred on disruptive innovation as follow:

T3a. Apps have a disruptive impact on current businesses and have transformed many aspects of business practices, providing new opportunities and a high level of innovation and of performance in the Companies.

T3b. The introduction of Apps has a disruptive impact on economies and traditional businesses, thus the innovation that are generated influences Companies and lead to new opportunities.

T3c. Apps have a disruptive impact on global economy and the generated influence on traditional business and people lead to new opportunities.

\subsubsection{Systemic Approach}

Apps Economy is an Ecosystem that can be studied by adopting a multi-level Systemic Approach (Dominici, \& Levanti, 2011; Tani, Papaluca \& Sasso, 2019). In fact, in the App Economy there are several kinds of actors and enabling technologies that are able to interact and influence each other. So, App Ecosystem can be seen as a complex adaptive system characterized by planned evolution, driven by both top-down and bottom-up processes, and composed of various interconnecting parts that, at the same time, can be seen as wholes at different levels (Tani, Basile, Dominici, 2019). Each actor of App Ecosystem - who we call stakeholder (Freeman, 1984) - has own specificity and works in the App Ecosystem with own methods and goals.

Over the years, stakeholders have worked together in order to ensure that App Economy continues upon its upward growth trajectory (Kathuria \& Srivastav, 2014). Several stakeholders were involved at different stages of many projects and in a vast number of fields (Panteli, Pitsillides, Pitsillides \& Samaras, 2007). The multitude of stakeholders (OECD, 2013) that characterize the App Ecosystem can be summarized like in table 2.

Table 2. Stakeholders of the App Ecosystem

\begin{tabular}{|c|c|}
\hline Kind of Stakeholder & $\begin{array}{l}\text { Description } \\
\end{array}$ \\
\hline Developers & $\begin{array}{l}\text { Who creates the applications and must identify in particular: the appropriate platforms, } \\
\text { the customer target and the earning potential }\end{array}$ \\
\hline Software platforms and stores & Main of them are Android, Symbian, iOS, Windows, BlackBerry, Bada \\
\hline Operating System Companies & i.e. Microsoft, Apple, Linux and others. \\
\hline Government and Policymakers & $\begin{array}{l}\text { Institutions, International Organizations, Regulators and Authorities (such as Antitrust or } \\
\text { Guarantee in Communications and Privacy) }\end{array}$ \\
\hline Consumers. & Users, Companies, Institutions, Administrations, Government \\
\hline Associations and NGOs & Various non-governmental Organizations and non-profit organizations \\
\hline Financial community & Banks, Financial backers / funders, Investors \\
\hline Founders or potential founders & Actors with Apps to build / test \\
\hline Shareholders & Players of App-based startups or companies \\
\hline Workers/Employees & $\begin{array}{l}\text { Various categories, including employees of Multinationals, Internet Companies, Analysts, } \\
\text { Managers, Technicians, and others }\end{array}$ \\
\hline Competitors & Both in terms of Apps developed, and the related services, and in terms of platforms \\
\hline Mobile Device manufacturers & i.e. Smartphones and Tablets \\
\hline $\begin{array}{l}\text { Telecommunications network } \\
\text { operators }\end{array}$ & Which provide networks and connectivity \\
\hline
\end{tabular}

In the App Economy, it is possible to distinguish in particular three main activities (Kathuria \& Srivastav, 2014): App development (freelance software, developers, multinational corporations, internet companies such as Google, and App analytics companies), distribution (App stores, HTML5, social networks) and demand (users, companies, public and government agencies).

The App Ecosystem is in a fast growth stage and each stakeholder play a meaningful role. As OECD (2013:18) reported "The Ecosystem for Apps includes various players and depending on the country stakeholders can play a larger or lesser role, depending on the conditions of the market". The same OECD report highlighted how in different countries the App value chain whose composed by different actors. A basic assumption is that the value of platforms increases with the number of Apps they may intermediate, the number of users, and the variety of handset options for users. In fact, one of the main goals by providers is to attract more users and developers.

In this scenario, also network effects assume a significant importance (Dubè, Hitsch \& Chintagunta, 2010). There are strategic transactions behind the Apps economy, economic drivers and potential bottlenecks or areas of competitive concern (OECD, 2013).

So, our tenets on the App Economy referred on Systemic Approach can be defined as follow:

T4a. The development of an App Economy has many stakeholders in different fields, with different value creation process. 
T4b. The App Ecosystem's stakeholders are tightly linked so the effects felt by some of them will reverberate on the others.

\section{Conclusion and Suggestions for Further Researches}

This paper focuses on the innovative phenomenon of App Economy, and it is aimed at proposing eight new tenets by focusing on four main theories, i.e. Transaction Costs Theory, Regulation, Disruptive Innovation Theory and Systemic Approach.

This work tries to delineate common denominators through the tenets within the extant literature that may serve as foundational to understanding the App Economy in a comprehensive way that is useful to scholars and practitioners.

This paper expands the current literature on App Economy trought the proposed of an original construct. The concept of App economy is delimited, as it analyzes well known parameters and applies them in different fields of the global economy. This study differs from others in terms of new tenets and tries to improve the knowledge of App Economy and to understand how new theories will be able to explain the impact of this phenomenon.

Drawing on a configurational multiple-theory perspective, our contribution is twofold. The tenets developed here summarizes important, and neglected, parameters of past research in the digital field. It also offers orientation and guidance for future empirical research as well as key concepts to build on. The tenets proposed, and the resulting construct could be employed in several stages of the App Economy for different purposes. Therefore, this paper tries to stimulate contribution to the current App Economy literature focused on the investigation of the development of this phenomenon and the future scenarios.

Our tenets, and theories related to the App Economy, can easily find empirical testing. One of their advantages in fact is the flexibility and adaptability to different contexts, such as the development of Apps characterized by high uncertainty and information asymmetries, or to explain the growth or spread of the phenomenon.

This study - hopefully - could have interesting and useful implications for several innovation ecosystem stakeholders such as enterprises, managers, entrepreneurs, app developers, operators, and policy makers.

This paper has some limitations that need to be underlined. The first limitation deals with the absence of similar studies, thus not allowing comparison. In the current literature there is a scarcity of paper that investigates the App Economy, its development and its future perspectives. The second limitation is that we proposed eight tenets and focus on several aspects related to the four theories, however it is not possible to exclude that there may be other parameters that can be used for the same purpose. Finally, we have proposed a model in which the theories are disconnected from each other but connected to the App Economy. Instead of, it would have been more interesting to formulate an evolution of the model which - in addition to identifying the tenets that link the different theories to the phenomenon - presented the tenets that link the theories and, simultaneously, explain the App Economy.

This study seeks to make a first few steps towards an understanding of further aspects of the App Economy and it represents a first attempt to the future perspectives of the innovative phenomenon. It could be interesting to replicate our study in different contexts - i.e. USA -, analyzing the phenomenon between several Countries and in other development further stages, in order to disclose and compare the differences. Based on this first study, a next paper could extend the theoretical framework based on the four theories, introduce additional tenets and add specific measures for each tenet. Another step of development of the study, could be a collet of a significant dataset, through a survey to several stakeholders of the App Economy. In this case, we could formulate the hypotheses related to the above cited tenets and could test them based on the collected data, to verify the effective link between them and the App Economy. A possible alternative to a quantitative analysis, could be the use of a qualitative method, such as a multiple case studies, to analyse the different stakeholder approaches to phenomenon in the field of the App Economy.

\section{References}

Akbar, Y. H., \& Tracogna, A. (2018). The sharing economy and the future of the hotel industry: Transaction cost theory and platform economics. International Journal of Hospitality Management, 71, 91-101. https://doi.org/10.1016/j.ijhm.2017.12.004

American Psychological Association. (1972). Ethical standards of psychologists. Washington, DC: American Psychological Association.

Anderson, C. A., Gentile, D. A., \& Buckley, K. E. (2007). Violent video game effects on children and adolescents: Theory, research and public policy. https://doi.org/10.1093/acprof:oso/9780195309836.001.0001 
App Annie. (2016). Retrospective - Mobile's Continued Momentum. Retrieved from https://www.appannie.com/en/insights/market-data/app-annie-2016-retrospective/

App Annie. (2018). The 2017-2022 App Economy Forecast: 6 Billion Devices, $\$ 157$ Billion in Spend \& More. Retrieved from https://www.appannie.com/en/insights/market-data/app-annie-2017-2022-forecast/

Arora, S., Ter Hofstede, F., \& Mahajan, V. (2017). The Implications of Offering Free Versions for the Performance of Paid Mobile Apps. Journal of Marketing, 81(6), 62-78. https://doi.org/10.1509/jm.15.0205.

Ashton, K. (2009). That 'internet of things' thing. RFID journal, 22(7), 97-114. Retrieved from http://www.itrco.jp/libraries/RFIDjournal-That\%20Internet\%20of\%20Things\%20Thing.pdf

Aungst, T. D. (2013). Medical applications for pharmacists using mobile devices. Ann Pharmacother, 47(7-8), 1088-1095. https://doi.org/10.1345/aph.1S035

Basili, M., \& Rossi, M. A. (2019). Platform-mediated reputation systems in the sharing economy and incentives to provide service quality: the case of ridesharing services. Electronic Commerce Research and Applications. https://doi.org/10.1016/j.elerap.2019.100835

Beck, C. A. J., \& Sales, B. D. (2001). Family mediation: Facts, myths, and future prospects (pp. 100-102). Washington, DC: American Psychological Association. https://doi.org/10.1037/10401-000

Bernstein, T. M. (1965). The careful writer: A modern guide to English usage (2nd ed.). New York, NY: Atheneum.

Bjork, R. A. (1989). Retrieval inhibition as an adaptive mechanism in human memory. In H. L. Roediger III, \& F. I. M. Craik (Eds.), Varieties of memory \& consciousness (pp. 309-330). Hillsdale, NJ: Erlbaum.

Bower, J. L., \& Christensen, C. M. (1995). Disruptive technologies: Catching the wave. Harvard Business Review, 73(1), 43-53. https://doi.org/10.1016/0024-6301(95)91075-1

Bresnahan, T. F., Davis, J. P., \& Yin, P. L. (2015). Economic Value Creation in Mobile Applications. In Jaffe, A.B. \& Jones, B. F. (Eds.). The changing frontier: Rethinking science and innovation policy (pp. 233-286). London: University of Chicago Press. https://doi.org/10.7208/chicago/9780226286860.003.0009

Busenbark, J. R., Krause, R., Boivie, S., \& Graffin, S. D. (2016). Toward a Configurational Perspective on the CEO: A Review and Synthesis of the Management Literature. Journal of Management, 42(1), 234-268. https://doi.org/10.1177/0149206315618448

Cecere, G., Le Guel, F., \& Lefrere, V. (2018). Economics of free mobile applications: personal data as a monetization strategy. Paper presented at the 16th Conference of IAOS OECD Headquarters, Paris, France, 19-21 September 2018. Retrieved from http://www.oecd.org/iaos2018/programme/IAOS-OECD2018_Lefrere-Cecere-LeGuel.pdf

Chen, Q., Zhang, M., \& Zhao, X. (2017). Analysing customer behaviour in mobile app usage. Industrial Management \& Data Systems, 117(2), 425-438. https://doi.org/10.1108/IMDS-04-2016-0141.

Chisholm, A., \& Jung, N. (2015). Platform regulation-ex-ante versus ex-post intervention: evolving our antitrust tools and practices to meet the challenges of the digital economy. Competition Policy International, 11(1). Retrieved from http://cpijournal.com/index.php/cpi/article/viewFile/169/31

Christensen, C. M. (1997). The Innovator's Dilemma: When New Technologies Cause Great Firms to Fail. Boston: Harvard Business School Press.

Christensen, C. M., \& Bower, J. L. (1996). Customer power, strategic investment, and the failure of leading firms. Strategic Management Journal, 17(3), 197-218.

https://doi.org/10.1002/(SICI)1097-0266(199603)17:3<197::AID-SMJ804>3.0.CO;2-U

Christensen, C. M., \& Overdorf, M. (2000). Meeting the challenge of disruptive change. Harvard Business Review, 78(2), 66-76. Retrieved from http://innovbfa.viabloga.com/files/HBR__Christensen__meeting_the_challenge_of_disruptive_change_ _2009.pdf

Christensen, C. M., \& Raynor, M. (2003). The Innovator's Solution: Creating and Sustaining Successful Growth. Boston: Harvard Business School Press, Boston.

Coase, R. H. (1937). The nature of the firm. Economica, 4(16), 386-405. https://doi.org/10.1111/j.1468-0335.1937.tb00002.x

Conroy, D. E., Yang, C. H., \& Maher, J. P. (2014). Behavior Change Techniques in Top-Ranked Mobile Apps for 
Physical Activity. American Journal of Preventive Medicine, 46(6), 649-652.

https://doi.org/10.1016/j.amepre.2014.01.010

Cortez, N. (2014). Regulating disruptive innovation. Berkeley Tech. LJ, 29, 175-228. Retrieved from https://heinonline.org/HOL/Page?handle=hein.journals/berktech29\&div=7\&g_sent=1\&casa_token=KbQem SZ7tnQAAAAA:H81v9MhcGT64N25kQ_BsXqYdI8bmZxs-Y0gD4zM5bmLZEen9Qu5t_opVr0q53BSDK OrMPRw-\&collection=journals

Cramer, J., \& Krueger, A. B. (2016). Disruptive change in the taxi business: the case of Uber. American Economic Review, 106(5), 177-182. https://doi.org/10.1257/aer.p20161002

Cress, C. M. (2009). Curricular strategies for student success and engaged learning [PowerPoint slides]. Retrieved from http://www.vtcampuscompact.org/2009/TCL_post/presenter_powerpoints/Christine\%20Cress\%20-\%20Curr icular\%20Strategies.ppt

Danneels, E. (2004). Disruptive technology reconsidered: A critique and research agenda. Journal of Product Innovation Management, 21, 246-258. https://doi.org/10.1111/j.0737-6782.2004.00076.x

Demers, C. (2007). The Configurational Perspective. In Demers, C. (Ed.). Organizational Change Theories: A Synthesis (pp. 47-59). Thousand Oaks: Sage.

Denning, S. (2014). An economy of access is opening for business: Five strategies for success. Strategy \& Leadership, 42(4), 14-21. https://doi.org/10.1108/SL-05-2014-0037

Dinsmore, J. B., Dugan, R. G., \& Wright, S. A. (2016). Monetary vs. nonmonetary prices: differences in product evaluations due to pricing strategies within mobile applications. Journal of Strategic Marketing, 24(3-4), 227-240. https://doi.org/10.1080/0965254X.2015.1108355.

Dinsmore, J. B., Swani, K., \& Dugan, R. G. (2017). To "Free" or Not to "Free": Trait Predictors of Mobile App Purchasing Tendencies. Psychology and Marketing, 34(2), 227-244. https://doi.org/10.1002/mar.20985.

Dominici, G., \& Levanti, G. (2011). The complex system theory for the analysis of inter-firm networks: a literature overview and theoretic framework. International Business Research, 4(2), 31-37. https://doi.org/10.5539/ibr.v4n2p31

Doty, D. H., Glick, W. H., \& Huber, G. P. (1993). Fit, equifinality, and organizational effectiveness: A test of 2 configurational theories. Academy of Management Journal, 36(6), 1196-1250. https://doi.org/10.2307/256810

Driedger, S. D. (1998, April 20). After divorce. Maclean's, 111(16), 38-43.

Drover, W., Wood, M. S., \& Tyge Payne, G. (2013). The Effects of Perceived Control on Venture Capitalist Investment Decisions: A Configurational Perspective. Entrepreneurship Theory and Practice, 38(4), 833-861. https://doi.org/10.1111/etap.12012

Dubè, J. P. H., Hitsch, G. J., \& Chintagunta, P. K. (2010). Tipping and Concentration in Markets with Indirect Network Effects. Marketing Science, 29(2), 216-249. https://doi.org/10.1287/mksc.1090.0541

Dudley, G., Banister, D., \& Schwanen, T. (2017). The rise of Uber and regulating the disruptive innovator. Political Quarterly, 88(3), 492-499. https://doi.org/10.1111/1467-923X.12373

EPRS - European Parliamentary Research Service. (2018). European app economy - State of play, challenges and EU policy, 1-8. Retrieved from http://www.europarl.europa.eu/RegData/etudes/BRIE/2018/621894/EPRS_BRI(2018)621894_EN.pdf

Ert, E., Fleischer, A., \& Magen, N. (2016). Trust and reputation in the sharing economy: The role of personal photos in Airbnb. Tourism Management, 55, 62-73. https://doi.org/10.1016/j.tourman.2016.01.013

Farajallah, M., Hammond, R. G., \& Pénard, T. (2019). What drives pricing behavior in Peer-to-Peer markets? Evidence from the carsharing platform BlaBlaCar. Information Economics and Policy, 48, 15-31. https://doi.org/10.1016/j.infoecopol.2019.01.002

Freeman, R. E. (1984). Strategic management: A stakeholder approach, Boston: Pitman.

Freitas, J. S., Gonçalves, C. A., Cheng, L. C., \& Muniz, R. M. (2011). Parsimonious Determinants of Pre-Incubated Academic Spin-Offs Initial Performance: a Configurational Perspective. Journal of Technology Management \& Innovation, 6(2), 50-65. https://doi.org/10.4067/S0718-27242011000200004

Gibbs, J. T., \& Huang, L. N. (Eds.). (1991). Children of color: Psychological interventions with minority youth. 
San Francisco, CA: Jossey-Bass.

Gilbert, D. G., McClernon, J. F., Rabinovich, N. E., Sugai, C., Plath, L. C., Asgaard, G., ... Botros, N. (2004). Effects of quitting smoking on EEG activation and attention last for more than 31 days and are more severe with stress, dependence, DRD2 A 1 allele, and depressive traits. Nicotine and Tobacco Research, 6, 249-267. https://doi.org/10.1 080/1462220041 0001676305

Goldsmith, B. (2014). The Smartphone App Economy and App Ecosystems. In Goggin, G., \& Hjorth, L. (Eds.). (2014), The Routledge companion to mobile media (pp. 171-181). London: Routledge.

Goleman, D. (2009). What makes a leader? In D. Demers (Ed.), AHSC 230: Interpersonal communication and relationships (pp. 47-56). Montreal, Canada: Concordia University Bookstore. (Reprinted from Harvard Business Review, 76(6), 93-102, 1998).

Greckhamer, T. (2016). CEO Compensation in relation to worker compensation across countries: The configurational impact of country-level institutions. Strategic Management Journal, 37(4), 793-815. https://doi.org/10.1002/smj.2370

Green, B. B. (2015). BP here, there, and everywhere - mobile health applications (apps) and hypertension care. Journal of the American Society of Hypertension, 9(2), 137-139. https://doi.org/10.1016/j.jash.2014.12.010

Grønli, T. M., Hansen, J., Ghinea, G., \& Younas, M. (2014). Mobile Application Platform Heterogeneity: Android vs Windows Phone vs iOS vs Firefox OS. Paper presented at the IEEE 28th International Conference on Advanced Information Networking and Applications. Retrieved from https://www.researchgate.net/profile/Gheorghita_Ghinea/publication/269301609_Mobile_Application_Platf orm_Heterogeneity_Android_vs_Windows_Phone_vs_iOS_vs_Firefox_OS/links/56b9ea7008ae3b658a8a3 4c7/Mobile-Application-Platform-Heterogeneity-Android-vs-Windows-Phone-vs-iOS-vs-Firefox-OS.pdf

Guignon, C. B. (1998). Existentialism. In E. Craig (Ed.), Routledge encyclopedia of philosophy (Vol. 3, pp. 493-502). London, England: Routledge.

Guttentag, D. (2015). Airbnb: disruptive innovation and the rise of an informal tourism accommodation sector. Journal Current Issues in Tourism, 18(12), 1192-1217. https://doi.org/10.1080/13683500.2013.827159

Healey, D. (2005). Attention deficit/hyperactivity disorder and creativity: An investigation into their relationship (Unpublished doctoral dissertation). University of Canterbury, Christchurch, New Zealand.

Heirman, A., \& Clarysse, B. (2004). How and Why do Research-Based Start-Ups Differ at Founding? A Resource-Based Configurational Perspective. Journal of Technology Transfer, 29(3-4), 247-268. https://doi.org/10.1023/B:JOTT.0000034122.88495.0d

Henningsson, S., \& Kettinger, W. J. (2016). Understanding Information Systems Integration Deficiencies in Mergers and Acquisitions: A Configurational Perspective. Journal of Management Information Systems, 33(4), 942-977. https://doi.org/10.1080/07421222.2016.1267516

Henten, A., \& Windekilde, I. (2015). Transaction costs and the sharing economy. info, 18(1), 1-15. https://doi.org/10.1108/info-09-2015-0044

Herculano-Houzel, S., Collins, C. E., Wong, P., Kaas, J. H., \& Lent, R. (2008). The basic nonuniformity of the cerebral cortex. Proceedings of the National Academy of Sciences, 105, 12593-12598. https://doi.org/10.1073/pnas.0805417105

Herrmann, P. (2005). Evolution of strategic management: the need for new dominant designs. International Journal of Management Reviews, 7(2), 111-130. https://doi.org/10.1111/j.1468-2370.2005.00108.x

Hew, J., Lee, V., Ooi, K., \& Wei, J. (2015). What catalyses mobile apps usage intention: an empirical analysis. Industrial Management \& Data Systems, 115(7), 1269-1291. https://doi.org/10.1108/IMDS-01-2015-0028

Hoehle, H., \& Venkatesh, V. (2011). Mobile application usability: conceptualization and instrument development. MIS Quarterly, 39(2), 435-472. https://doi.org/10.25300/MISQ/2015/39.2.08

Hofman, E., Faems, D., \& Schleimer, S. C. (2017). Governing Collaborative New Product Development: Toward a Configurational Perspective on the Role of Contracts. Journal of Product Innovation Management, 34(6), 739-756. https://doi.org/10.1111/jpim.12412

Holzer, A., \& Ondrus, J. (2011). Mobile application market: A developer's perspective. Telematics and Informatics, 28(1), 22-31. https://doi.org/10.1016/j.tele.2010.05.006

Homburg, C., Workman, J. P. J., \& Jensen, O. (2002). A Configurational Perspective on Key Account 
Management. Journal of Marketing, 66(2), 38-60. https://doi.org/10.1509/jmkg.66.2.38.18471

Hoskisson, R. E., Hitt, M. A., Wan, W. P., \& Yiu, D. (1999). Theory and research in strategic management: swings of pendulum. Journal of Management, 25(3), 417-456.

https://doi.org/10.1016/S0149-2063(99)00008-2

Islam, R., Islam, R., \& Mazumder, T. A. (2010). Mobile Application and Its Global Impact. International Journal of Engineering \& Technology IJET-IJENS, 10(6), 104-111. Retrieved from https://www.researchgate.net/profile/Dr_Md_Rashedul_Islam/publication/308022297_Mobile_application_ and_its_global_impact/links/5991fbafa6fdcc53b79b606d/Mobile-application-and-its-global-impact.pdf

Johnston, H. (2017). Workplace gains beyond the Wagner Act: The New York taxi workers alliance and participation in administrative rulemaking. Labor Studies Journal, 43(2), 141-165. https://doi.org/10.1177/0160449X17747397

Kathuria, R., \& Srivastav, S. (2014). The Indian app ecosystem. Report for the Indian Council for Research on International Economic Relations. Retrieved from

http://broadbandasia.info/wp-content/uploads/2013/03/The-Indian-App-Ecosystem-Final-Report_afterEF20 14. pdf

Khalaf, S., \& Kesiraju, L. (2017). US consumers time-spent on mobile crosses 5 hours a day. Flurry Analytics. Retrieved from http://flurrymobile.tumblr.com/post/157921590345/us-consumers-timespent-on-mobile-crosses-5

Klimoski, R., \& Palmer, S. (1993). The ADA and the hiring process in organizations. Consulting Psychology Journal: Practice and Research, 45(2), 10-36. https://doi.org/10.1037/1061-4087.45.2.10

Kostoff, R. N., Boylan, R., \& Simons, G. R. (2004). Disruptive technology roadmaps. Technological Forecasting and Social Change, 71(1-2), 141-159. https://doi.org/10.1016/S0040-1625(03)00048-9

Kubrick, S. (Director). (1980). The Shining [Motion picture]. United States: Warner Brothers.

Liu, S. (2005). Defending against business crises with the help of intelligent agent based early warning solutions. Paper presented at the Seventh International Conference on Enterprise Information Systems, Miami, FL. Abstract retrieved from http://www.iceis.org/iceis2005/abstracts_2005.htm

Ma, L., Gu, L., \& Wang, J. (2014). Research and Development of Mobile Application for Android Platform. International Journal of Multimedia and Ubiquitous Engineering, 9(4), 187-198. https:://doi.org/10.14257/ijmue.2014.9.4.20

MacIntyre, L. (Reporter). (2002, January 23). Scandal of the Century [Television series episode]. In H. Cashore (Producer), The fifth estate. Toronto, Canada: Canadian Broadcasting Corporation.

MacMillan, D., \& Burrows, P. (2009). Inside the App Economy. Retrieved from https://www.bloomberg.com/news/articles/2009-10-22/inside-the-app-economy

Mahoney, T. J., \& McGahan, A. M. (2007). The field of strategic management within the evolving science of strategic organization. Strategic Organization, 5(1), 79-99. https://doi.org/10.1177/1476127006074160

Mandel, M., \& Scherer, J. (2012). The geography of the app economy. CTIA: The Wireless Association, 1-34. Retrieved from http://files.ctia.org/pdf/The_Geography_of_the_App_Economy.pdf

Markides, C. (2006). Disruptive innovation: In need of better theory. Journal of Product Innovation Management, 23, 19-25. https://doi.org/10.1111/j.1540-5885.2005.00177.x

McLuhan, M. (1970a). Culture is our business. New York, NY: McGraw-Hill.

McLuhan, M. (1970b). From cliche to archetype. New York, NY: Viking Press.

Mellahi, K., \& Sminia, H. (2009). Guest Editors' Introduction: The frontiers of strategic management research. International Journal of Management Reviews, 11(1), 1-7. https://doi.org/10.1111/j.1468-2370.2008.00248.x

Mellers, B. A. (2000). Choice and the relative pleasure of consequences. Psychological Bulletin, 126, $910-924$. https://doi.org/10.1037/0033-2909.126.6.910

Meyer, A. D., Tsui, A. S., \& Hinings, C. R. (1993). Configurational approaches to organizational analysis. Academy of Management Journal, 36(6), 1175-1195. https://doi.org/10.2307/256809

Miller, D. (1990). Organizational configurations: cohesion, change, and prediction. Human Relations, 43(8), 
771-789. https://doi.org/10.1177/001872679004300805

Miller, D. (1996). Configurations revisited. Strategic Management Journal, 17(7), 505-512. https://doi.org/10.1002/(SICI)1097-0266(199607)17:7<505::AID-SMJ852>3.0.CO;2-I

Miller, D., \& Le Breton-Miller, I. (2006). Priorities, practices and strategies in successful and failing family businesses: an elaboration and test of the configuration perspective. Strategic Organization, 4(4), 379-407. https://doi.org/10.1177/1476127006069575

Mulligan, M., \& Card, D. (2014). Sizing the EU app economy. Gigaom Research, 1-16. Retrieved from http://i.co.uk/wp-content/uploads/2014/02/SizingtheEUappeconomy-FullReportFeb14.pdf

OECD. (2013). The App Economy. Oecd Digital Economy Papers, 230, 1-56. https://doi.org/10.1787/5k3ttftlv95k-en

Oei, S. Y., \& Ring, D. M. (2017). The tax lives of Uber drivers: Evidence from Internet discussion forums. Columbia Journal of Tax Law, 8(1), 56-112. Retrieved from http://lawdigitalcommons.bc.edu/cgi/viewcontent.cgi?article=2048\&context=lsfp

Oriwoh, E., \& Conrad, M. (2015). 'Things' in the Internet of Things: towards a definition. International Journal of Internet of Things, 4(1), 1-5. Retrieved from http://www.sapub.org/global/showpaperpdf.aspx?doi=10.5923/j.ijit.20150401.01

Palekar, S., Weerasinghe, K., \& Sedera, D. (2013). Disruptive innovation of mobile communication apps. In Deng, H., \& Standing, C. (Eds). ACIS 2013: Information systems: Transforming the Future: Proceedings of the 24th Australasian Conference on Information Systems. In 24th Australasian Conference on Information Systems (ACIS) (pp. 1-10). Melburne: RMIT University.

Panteli, N., Pitsillides, B., Pitsillides, A., \& Samaras, G. (2007). An E-healthcare Mobile application: A Stakeholders' analysis. In Al-Hakim, L. (Ed.), Web mobile-based applications for healthcare management (pp. 101-117). USA: Idea Group. https://doi.org/10.4018/978-1-59140-658-7.ch004

PEW Research Center. (2019). Mobile Fact Sheet - Mobile phone ownership over time. Retrieved from https://www.pewresearch.org/internet/fact-sheet/mobile/

Postman, N. (1979). Teaching as a conserving activity. New York, NY: Delacorte Press.

Postman, N. (1985). Amusing ourselves to death: Public discourse in the age of show business. New York, NY: Viking.

PPI - Progressive Policy Institute. (2017). The App Economy in Europe: Leading Countries and Cities, 1-21. Retrieved from https://www.progressivepolicy.org/wp-content/uploads/2017/10/PPI_EuropeAppEconomy_2017_.pdf

Puschmann, T., \& Alt, R. (2016). Sharing Economy. Business \& Information Systems Engineering, 58(1), 93-99. https://doi.org/10.1007/s12599-015-0420-2

Rakestraw, T. L., Eunni, R. V., \& Kasuganti, R. R. (2013). The mobile apps industry: A case study. Journal of Business Cases and Applications, 74-98. Retrieved from https://pdfs.semanticscholar.org/b4fd/972d8f34de5d8c5eeec805b94642b1610223.pdf

Raymond, L., \& Croteau, A. (2006). Enabling the strategic development of SMEs through advanced manufacturing systems. Industrial Management \& Data Systems, 106(7), 1012-1032. https://doi.org/10.1108/02635570610688904

Remane, G., Hanelt, A., Nickerson, R. C., \& Kolbe, L. M. (2017). Discovering digital business models in traditional industries. Journal of Business Strategy, 38(2), 41-51. https://doi.org/10.1108/JBS-10-2016-0127

Rochet, J. C., \& Tirole, J. (2003). Platform competition in two-sided markets. Journal of the European Economic Association, 1(4), 990-1029. https://doi.org/10.1162/154247603322493212

Semenak, S. (1995, December 28). Feeling right at home: Government residence eschews traditional rules. Montreal Gazette, p. A4.

Serrano, N., Hernantes, J., \& Gallardo, G. (2013). Mobile Web Apps. IEEE Software, 30(5), 22-27. https://doi.org/10.1109/MS.2013.111

Simon, H. A. (1957). Administrative Behavior. New York: Macmillan

Simon, H. A. (1985). Causalità, razionalità, organizzazione. Bologna: Il Mulino. 
Straatmann, T., Rothenhofer, L., Meier, A., \& Mueller, K. (2018). A Configurational Perspective on the Theory of Planned Behaviour to Understand Employees' Change-Supportive Intentions. Applied Psychology, 67(1), 91-135. https://doi.org/10.1111/apps.12120

Tani, M., Basile, G., \& Dominici, G. (2019). Place brand as an emergent property: The case of Vascitour and Naples. Systems Research and Behavioral Science, 1-14. https://doi.org/10.1002/sres.2659

Tani, M., Papaluca, O., \& Sasso, P. (2018). The system thinking perspective in the open-innovation research: A systematic review. Journal of Open Innovation: Technology, Market, and Complexity, 4(3), 38. https://doi.org/10.3390/joitmc4030038

Taylor, G. D., \& Levin, M. (2014). Predicting mobile app usage for purchasing and information-sharing. International Journal of Retail \& Distribution Management, 42(8), 759-774. https://doi.org/10.1108/IJRDM-11-2012-0108

Troise, C., \& Ferrara, E. (2016). App Economy: impatto ed effetti del fenomeno. Diritto ed economia dei mezzi di comunicazione, 2(2015-2016), 7-28.

Ventola, C. L. (2014). Mobile Devices and Apps for Health Care Professionals: Uses and Benefits. Pharmacy and Therapeutics, 39(5), 356-364. Retrieved from https://www.ncbi.nlm.nih.gov/pmc/articles/PMC4029126/

Wang, H. Y., Liao, C., \& Yang, L. H. (2013). What Affects Mobile Application Use? The Roles of Consumption Values. International Journal of Marketing Studies; 5(2), 12-22. https://doi.org/10.5539/ijms.v5n2p11

West, J., \& Mace, M. (2010). Browsing as the killer app: Explaining the rapid success of Apple's iPhone. Telecommunications Policy, 34(5-6), 270-286. https://doi.org/10.1016/j.telpol.2009.12.002

Williams, J. (2012). The value of mobile apps in health care: learn how mobile applications and technologies are improving quality of care, patient satisfaction, safety, and convenience-and reducing costs. Healthcare Financial Management, 66(6), 96-101. Retrieved from https://go.galegroup.com/ps/anonymous?id=GALE\%7CA300343014\&sid=googleScholar\&v=2.1\&it=r\&lin kaccess $=$ abs \&issn $=07350732 \& \mathrm{p}=\mathrm{AONE} \& \mathrm{sw}=\mathrm{w}$

Williamson, O. E. (1979). Transaction-cost economics: The governance of contractual relations. Journal of Law and Economics, 22, 233-261. http://dx.doi.org/10.1086/466942

Windsor, D. (2019). Influencing MNC strategies for managing corruption and favouritism in Pacific Asia countries: a multiple-theory configurational perspective. Asia Pacific Business Review, 25(4), 501-533. https://doi.org/10.1080/13602381.2019.1589769

Zervas, G., Proserpio, D., \& Byers, J. W. (2017). The Rise of the Sharing Economy: Estimating the Impact of Airbnb on the Hotel Industry. Journal of Marketing Research, 54(5), 687-705. https://doi.org/10.1509/jmr.15.0204

Zimmermann, A. (2011). Interpersonal relationships in transnational, virtual teams: Towards a configurational perspective. International Journal of Management Reviews, 13(1), 59-78.

https://doi.org/10.1111/j.1468-2370.2010.00284.x

Notes

Note 1. In 1985, Apple released the MacApp programming tool (Goldsmith, 2014).

\section{Copyrights}

Copyright for this article is retained by the author(s), with first publication rights granted to the journal.

This is an open-access article distributed under the terms and conditions of the Creative Commons Attribution license (http://creativecommons.org/licenses/by/4.0/). 